\title{
Writing approaches and strategies used by teachers in selected South African English First Additional Language classrooms
}

\begin{tabular}{|c|c|}
\hline \multicolumn{2}{|c|}{$\begin{array}{l}\text { Authors: } \\
\text { Nomalungelo I. Ngubane }{ }^{1} \\
\text { Berrington Ntombela }{ }^{2} \text { () } \\
\text { Samantha Govender }{ }^{3}\end{array}$} \\
\hline \multicolumn{2}{|c|}{$\begin{array}{l}\text { Affiliations: } \\
{ }^{1} \text { Department of Languages and } \\
\text { Media, School of Education, } \\
\text { Faculty of Humanities, } \\
\text { University of KwaZulu-Natal, } \\
\text { Durban, South Africa }\end{array}$} \\
\hline \multicolumn{2}{|c|}{$\begin{array}{l}{ }^{2} \text { Department of English, Faculty } \\
\text { of Arts, University of Zululand, } \\
\text { Empangeni, South Africa }\end{array}$} \\
\hline \multicolumn{2}{|c|}{$\begin{array}{l}{ }^{3} \text { Department of Curriculum } \\
\text { Studies, Faculty of Education, } \\
\text { University of Zululand, } \\
\text { Empangeni, South Africa }\end{array}$} \\
\hline \multicolumn{2}{|c|}{$\begin{array}{l}\text { Corresponding author: } \\
\text { Nomalungelo Ngubane, } \\
\text { ngubanen3@ukzn.ac.za }\end{array}$} \\
\hline \multicolumn{2}{|c|}{$\begin{array}{l}\text { Received: } 19 \text { Aug. } 2019 \\
\text { Accepted: } 08 \text { Apr. } 2020 \\
\text { Published: } 18 \text { June } 2020\end{array}$} \\
\hline \multicolumn{2}{|c|}{$\begin{array}{l}\text { How to cite this article: } \\
\text { Ngubane, N.I., Ntombela, B. \& } \\
\text { Govender, S., 2020, 'Writing } \\
\text { approaches and strategies } \\
\text { used by teachers in selected } \\
\text { South African English First } \\
\text { Additional Language } \\
\text { classrooms', Reading \& } \\
\text { Writing 11(1), a261. https:// } \\
\text { doi.org/10.4102/rw.v11i1.261 }\end{array}$} \\
\hline \multicolumn{2}{|c|}{$\begin{array}{l}\text { Copyright: } \\
\text { (C) 2020. The Authors. } \\
\text { Licensee: AOSIS. This } \\
\text { is licensed under the } \\
\text { Creative Commons } \\
\text { Attribution License. }\end{array}$} \\
\hline \multicolumn{2}{|l|}{ Read online: } \\
\hline 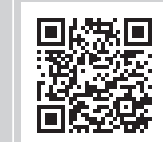 & $\begin{array}{l}\text { Scan this QR } \\
\text { code with your } \\
\text { smart phone or } \\
\text { mobile device } \\
\text { to read online. }\end{array}$ \\
\hline
\end{tabular}

Background: The teaching of writing in English First Additional Language (EFAL) classrooms remains less explored in the Further Education and Training Phase (FET) in South Africa. This is so despite research showing a decline in the writing skills of second language learners, especially at the FET phase, calling attention to how writing is taught.

Objectives: The purpose of this study was to investigate writing approaches and teaching strategies used by teachers in teaching writing in selected EFAL FET classrooms in the Pinetown district.

Method: A qualitative approach was adopted to observe five writing lessons across five schools using a video camera. Discourse analysis was used to analyse data.

Results: The findings indicate that teachers mostly used a process approach to writing, which is in line with their curriculum. The study also found that teachers generally used a question and answer method to teach writing, which entails teachers controlling the interactions in the classrooms through a nomination-response cycle. Analyses of lessons also suggest that teachers creatively employed code-switching to explain writing concepts better.

Conclusion: The study concludes that the effectiveness of any pedagogy depends on the teachers' knowledge and understanding of writing and approaches to writing. For effective development of learners' writing, the study recommends instruction methods that embrace collaborative writing activities in the learners' Zone of Proximal Development (ZPD) and the recognition of learners' home languages.

Keywords: narrative essay; English First Additional Language; discourse analysis; codeswitching; collaborative learning; Zone of Proximal Development.

\section{Introduction}

The declining level of writing skills among English First Additional Language (EFAL) learners is a concern (Akinyenye 2012; Blease \& Condy 2015; Pineteh 2014). In South Africa, poor writing skills of learners have been mostly associated with teachers' lack of knowledge of effective writing approaches to constructively support the development of writing, especially among second language learners (Blease \& Condy 2015). Many teachers in EFAL classrooms have limited understanding of the writing approaches and as such, they use inappropriate writing strategies in their classrooms (Dornbrack \& Atwood 2019). Even though the Curriculum and Assessment Policy Statement (CAPS) (Department of Basic Education, 2012) advocates for the use of the process approach to writing, limited training opportunities on the use of this approach has been offered to teachers (Dornbrack \& Dixon 2014). Many teachers, therefore, struggle to translate the curriculum into practice. Alongside these pedagogical challenges, Pineteh (2014) noted that most teachers possess inadequate writing skills. They are not writers. This also affects their attitudes towards writing and the teaching of writing. This could be one of the reasons why scholars (Akinyenye 2012; Ngubane 2018) observed very little writing practices taking place in EFAL classrooms.

Despite the challenges associated with the teaching of writing reported by the studies discussed above, and the fact that these teaching challenges have far-reaching implications on the development of writing among learners, very little research in South Africa has paid attention to the writing approaches and strategies used by EFAL teachers, especially at the Further Education and Training Phase (FET) to enhance learners' writing practices. Most studies (Akinyenye 2012; Julius 2013) focus 
on writing experiences in the Foundation, Intermediate and Senior phases. Not much is known about the writing approaches in EFAL FET classrooms. Writing pedagogy in EFAL FET classrooms, 3 years prior to learners completing high school and joining higher education, cannot be ignored since it has implications for learners' writing competencies for post-school education (Dornbrack \& Atwood 2019). This study, therefore, investigates the writing approaches and teaching strategies used by teachers in EFAL FET classrooms in the Pinetown district, South Africa. The study was guided by the following question: What writing approaches and teaching strategies are used by teachers in EFAL FET writing classrooms?

\section{Related literature}

Blease and Condy (2015) argue that writing is one of the most important language skills. It plays a significant role in the learning of language and for that reason writing cannot be ignored. Writing is a tool for the creation and the expression of ideas. It is also a means for the consolidation of linguistic structures when it is used for interactive communication (Isleem 2012). Isleem (2012) also believes that it is through writing that learners develop critical skills like innovation, creativity and self-expression; these skills are essential for academic success. In the same vein, writing is significant for accountability in standardised assessments across the schooling curriculum (Akinyenye 2012). Furthermore, writing practice helps learners use their target language and explore various linguistic elements like grammar, idioms and vocabulary in their texts, and with more writing opportunities they can become better writers (Isleem 2012). Richards (2006) discovered a close link between thinking and writing which renders writing a crucial practice to develop among learners. Similarly, Dornbrack and Atwood (2019) argue that writing activities in which learners are encouraged to brainstorm ideas, to be innovative and to think critically cultivate cognitive development essential for successful learning and post-school life. Moreover, the ability to organise own thoughts and information through writing is a valuable skill for learning and post-school success.

Teaching approaches lie at the centre of teaching and learning (Leach \& Moon 2008). It is what teachers need to know and the skills they need to command in order to make and justify the kinds of decisions that constitute teaching. Furthermore, effective approaches are the cornerstone for active learning. In writing classrooms, teaching strategies refer to classroom ways of talking, showing and guiding, active participation so that the unknowing can come to know, those without understanding can comprehend and discern, and the unskilled become adept (Leach \& Moon 2008). Leach and Moon (2008) define teaching methods as:

$[M]$ ore than the accumulation of techniques and strategies, more than arranging a classroom, more than formulating questions and developing explanations, but it is informed by a view of mind, of learning, learners, the kinds of knowledge, and outcomes that are valued. (p. 6)

In a writing classroom, a teaching strategy would be influenced by the teacher's beliefs and attitude about writing, his or her other knowledge about writing, learners' writing abilities and proficiency levels, curriculum, as well as his or her objectives for the writing lessons (Lee 2008). Effective writing pedagogy is, therefore, a key to the successful development of efficient writing skills among learners.

Even though we know much about writing strategies in many classrooms such as in China and Hong Kong (Lee 2008); Taiwan (Lan, Hung \& Hsu 2011); and Poland (Mohile 2014); little is known about the writing pedagogy in South African classroom contexts, especially is secondary schools. This is so because, according to Mpiti (2016), there is limited documented research on writing practices among second language learners and teachers in these contexts.

\section{Approaches to writing}

Product approach has been used in many writing classrooms since the 1970s (Escholz 1980). In a product approach, teachers usually present learners with a model text to emulate and construct their own texts. Escholz (1980) found that the product approach follows a traditional way of teaching writing as it demands that learners focus on the model, the form and the duplication of the teacher's text as much as possible. For example, teachers using the product approach put more focus on the grammatical features of the text and the organisation of the text rather than the ideas and the thoughts within the text (Ngubane 2018). Accuracy in writing is the main focus in the product approach instruction. Teachers assess learners' writing based on how accurate they are in grammar, spelling and punctuation. In some classes, Akinyenye and Pluddemann (2016) found that learners are asked to analyse the main components of the teacher's sample text and then copy the sample's organisational structure to reproduce as their texts. All in all, the goal of teaching writing in product approach classrooms is for learners to produce a text that is similar in form and language conventions to the one they have learned. Diversion in terms of creativity is less appreciated. While this approach is mostly criticised for its focus on the use of correct grammatical features, form and language features, such as spelling and punctuation; some scholars (Badger \& White 2000) think differently about the product approach. These scholars argue that the product approaches do recognise learners' need for linguistic development and competence across different texts for them to become efficient writers. Imitation is one method by which people learn. In other words, teachers are encouraged to balance the product approach with other writing approaches in order to effectively support the development of their learners' writing skills.

In a process approach, the focus of writing instruction is on the steps involved in drafting and redrafting texts (Nunan 1999). When learners write, they go through various similar stages as writers. These stages involve brainstorming or prewriting, writing, revising, editing and publishing (Flower \& Hayes 1986):

It is assumed that the stages of the writing process approach empower learners by enabling them to make decisions about the 
direction of their work through discussions, tasks, drafting, feedback and informed choices, thus enabling them to be responsible for making improvement themselves. (Raimes 1991:410)

Raimes (1991) identified basic stages of the writing process that teachers may implement in their classrooms:

- Pre-writing (selecting a topic and planning what to say)

- Writing (putting a draft version on paper)

- Revising (making changes to improve writing)

- Editing and proofreading (working on expression and punctuation)

- Evaluation (assessment of the written work)

According to Flower and Hayes (1981), these five stages allow learners to generate ideas before they begin to write, to revise their ideas back and forth and to edit their ideas before the publication of the final product. Tribble (1996:220) argues that 'the process approach focuses on the learners' independent ability to produce coherent texts after going through writing activities in stages'. This implies that in the process approach, the learners are given opportunities to be in control of their writing, while the teacher plays the role of supporting the development of writing by guiding and supporting. Contrary to the product approach, learners in the process approach are not expected to complete and produce a draft of the text; however, they are expected to go through 'processes of drafting and receiving feedback on their drafts, be it from peers and / or from the teacher, followed by revision of their evolving texts' (Tribble 1996:220-221). Feedback during the writing process is crucial as it helps the learner to see the weaknesses in his or her writing and thus improve before reaching the final stage of the writing process. The CAPS curriculum for EFAL FET phase also emphasises that teachers should use the writing process to develop the learners' writing skills. In particular, the curriculum emphasises that teachers should teach learners strategies of brainstorming before they write. Teachers should also make learners aware of the importance of editing their work before presenting a finished text (Dornbrack \& Atwood 2019).

Apart from the product and process approaches to teaching writing, the genre-based approach has also gained popularity as another approach to develop learners' writing skills. Developed from Martin's (1993) Systemic Functional Linguistic (SFL) model of language, the genre-based approach places greater emphasis on the social context in which writing is produced. At the heart of the genre-based approach is the perspective that teachers should teach learners the explicit and systematic explanations of the ways language functions in social contexts. Teachers in genrebased classrooms should, therefore, encourage learners to explore and exploit texts from different types of genres and thus be able to communicate in different contexts for different purposes and for different audiences. In explaining the role of the genre-based teacher, Mpiti (2016) stresses that the teacher takes the 'authoritative' role to 'scaffold' or support the learners through guided activities as they move towards their writing goal and potential level. This scaffolding pedagogical approach is underpinned by Vygotsky's (1978) socio-linguistic theory, which capitalises on the interactive and collaborative nature of a writing classroom. Vygotsky (1978) argues that scaffolding gradually lightens as the learners independently produce their own texts parallel to the model. At such a level, the role of the teacher then moves from explicit instructor to that of facilitator until learners gain writing independence.

Vygotsky (1978) proclaimed writing as a social practice. According to Vygotsky (1978), what learners learn about writing, whether right or wrong, is mostly influenced by their social practices. Similarly, DeLange, Dipenaar and Anker (2018) assert that learners develop and learn writing skills through 'active' participation within their social and cultural contexts, including their classroom. Writing as a social practice depends largely on the language and the teacher's ways of facilitating writing development. The role of the language teacher is to present writing as a means of interaction with others within the social context and thus use writing to share ideas about relevant issues affecting learners' social contexts. Teachers, according to Mpiti (2016), should also provide opportunities in the classroom for such articulation of ideas to take place through writing. 'The ultimate aim of any comprehensive approach to teaching writing is to produce confident, competent, and independent writers who write for people' (Blease \& Condy 2015:7). This means that if learners are to be effective writers, they must approach writing as a social practice and a purposeful task with intended readers in mind. Therefore, it is important for learners to write with a clear understanding of their audience.

\section{Methodology}

A qualitative framework underpinned this case study of five EFAL FET writing classrooms that were purposively sampled. Participants' consent was sought prior to data collection. Permission was obtained from the Department of Education and school principals. Five EFAL FET writing lessons were observed across five selected schools using a video camera. Each observed classroom had an average of 45 students between the ages of 15-19 years. Of the teachers who were observed, three were female between 35 and 50 years of age and two were male teachers between 40 and 55 years of age. All of them were from isiZulu home language backgrounds and spoke English as a second language. All the lessons were 55 minutes long. Classroom observation enabled the researcher to look directly at what was happening in the EFAL FET classroom, thus collecting data first-hand (Creswell 2009). Lessons were transcribed and analysed using the boundary exchanges and teaching exchanges model as proposed by Sinclair and Coulthard (1975). Three major categories of the model: meta-interactive, interactive and turn-taking were also used to analyse the lessons. The names of the five schools were replaced by School A, School B, School C, School D and School E during transcription of 
the lessons. Lessons were numerically labelled as Lesson 1, 2,3 , and so on.

\section{Data presentation and analysis}

This section presents data from classroom observation (writing lessons) to address the question on writing approaches and teaching strategies used by the teachers to teach writing. All classroom observations were video-recorded and thereafter each recorded lesson was transcribed verbatim. Only lesson excerpts that showcased the strategies used by teachers were selected for analysis. Learners' names were removed and replaced with the letter $X$ to protect their identities.

\section{Lesson 1, School A}

Duration of the lesson: $55 \mathrm{~min}$

1. Teacher: Okay [frame] today we are going look at the narrative essay [focus]. What does the word narrate mean? [elicitation] Yes X? [nomination]

2. Learner: To narrate, eeeh ... is to tell a story [response]

3. Teacher: Good, to narrate is to tell a story. It is very important. So, what are the elements of a narrative story? What things must be included in the story? Yes, $\mathrm{X}$ ?

4. Learner: Introduction.

5. Teacher: Introduction. Very good. You introduce your essay. What else? Yes X?

6. Learner: The body.

7. Teacher: Yes the body of the essay. But what must be in the body? What things are important in the body of the essay? The story.

8. Learner: The place.

To indicate a change from a greeting to a topic, the teacher begins with a frame 'okay' (line A1:1) and focuses the lesson on the narrative essay. The teacher then elicits the meaning of 'narrate'. The teacher then nominates (A1:1) learner $X$ to provide the correct answer. The learner responds in (A1:2). The teacher then provides feedback, accepting the learner's response and then proceeds to elicit the elements of a narrative essay. The lesson proceeds following the pattern: T-P-T (Teacher-Pupil-Teacher). This pattern indicates a flow of teacher-learner interaction in the classroom. It also shows that interactions are regulated by the teacher. It also shows that learners do not speak randomly in the classroom; they wait for the teacher to nominate them to speak. This is a common practice to maintain order and to control proceedings in the classroom (Sinclair \& Coulthard 1975).

The second stage of the lesson:

9. Teacher: Good. Now [frame], let us move on to the stages of a narrative writing. [focus] What is the first stage of writing? [elicitation]

10. Learners: Free writing.

11. Teacher: Free writing and?

12. Learners: Free writing and planning.

13. Teacher: Second stage?

14. Learners: Drafting.
Here the teacher focuses the lesson on the stages of narrative writing. The teacher does not provide learners with the stages of narrative writing but elicits them from the learners. The learners seemed to know these stages as they provide all the stages of the writing process when elicited by the teacher, for example in A1:12. (planning), A1:14. (drafting). Badger and White (2000) also agree that these are the stages of the writing process. Curriculum and Assessment Policy Statement curriculum suggests that teachers use the process approach to teach writing. The teacher, therefore, seems to be following the curriculum.

The lesson then progresses to the third stage where the teacher continues with the question and answer method as she provides more elicitations to help learners understand keywords in the topic which is another process of writing (Badger \& White 2000).

\section{Lesson 2, School B}

Duration of the lesson: $55 \mathrm{~min}$

The following extract shows how the teacher from School B taught narrative writing in her Grade 12 classroom:

1. Teacher: Okay [meta-interactive act] let us move on [directive]. What is the important thing to consider when writing your essay? [elicitation]

2. Learner: Introduction. [response]

3. Teacher: No. Before you even get to an introduction. Raise your hands. [cue] Yes, X. [nomination]

4. Learner: The topic of the essay.

5. Teacher: Good, X (name of the learner). Your topic of writing is the most important element that shapes your lines of thinking. [feedback]

6. Teacher: After the topic, what else must you think about?

7. Learner: Planning, sir.

8. Teacher: So how do you do the planning for your essay?

9. Learner: You brainstorm the topic, sir.

10. Teacher: Yes, you can brainstorm, you can brainstorm the topic, generating ideas or do a mind map, a flow chart or float lines. Now, why is planning important when you are doing a narrative essay? So when you are going to do an essay you should have planning, planning is going to serve as a guide as to how you are going to go about presenting your story.

In the above section of the lesson, the teacher uses the frame 'okay' to indicate that he is moving to the next stage of the lesson. The teacher elicits the important thing to consider when writing an essay. In the typical exchange of T-P-T, the learner responds with 'introduction', which the teacher rejects. It might seem that the learner who responded had spoken out of turn, because immediately when the teacher had rejected the response, he gives a cue that those who want to respond must bid for nomination by raising their hands. The teacher thereafter nominates a learner who responds 
'The topic of the sentence', which the teacher accepts. The teacher proceeds by eliciting more things to consider when writing an essay to which learners respond with 'planning' and 'brainstorming', which the teacher accepts.

The teacher emphasises that the topic of writing is the most important aspect of writing the essay as it shapes their thinking (B2:5). This implies that the teacher is well informed about the writing process that she is using to teach writing in her class. This is shown by the teacher's elicitation of the learners' understanding of the stages of writing through the question and answer method. The teacher elicits what learners think about the topic. The learner responded that planning is important (B2:7), and so is brainstorming (B2:9). This implies that the school follows the process approach to writing as recommended by the curriculum.

Interestingly, in the following stages of the lesson, the teacher spent more time explaining different aspects that form the body of a narrative essay such as the plot, climax and the characters. The teacher also stressed that the body of a narrative consists of a number of paragraphs. The focus on the structure of the body, that is, the paragraphs, is influenced by the product approach. This shows that the teacher draws from the process approach and the product approach to teach writing.

In the last stage of the lesson, the teacher put emphasis on the feelings, the mood, the tone and diction of a narrative as a genre. These aspects are specific to genres and they vary according to the type of texts learners are learning to write. The teaching of these aspects of writing implies the use of a genre approach in addition to the process and product approaches that the teacher used in the earlier stages of the lesson. All in all, the teacher in the above lesson draws from three approaches: process, product and genre approaches at different stages of her lesson to teach writing.

\section{Lesson 3, School C}

Duration of the lesson: $55 \mathrm{~min}$

The lesson on the writing of an invitation letter in Grade 10 classroom went like this:

1. Teacher: Konje ke iyini writing? (What is writing?)

2. Learner: (silence)

3. Teacher: Uma sibhala sibeka imicabango yethu, angithi? (When we write we express our thoughts, isn't it?)

4. Teacher: Today I want us to look at an invitation letter. Alright? [frame]

5. Learner: Yes.

6. Teacher: What is the reason for writing an invitation? $\mathrm{X}$ ?

7. Learner: To invite.

8. Teacher: Yes, (writing on the board) we write an invitation to invite someone to an occasion. What occasion can that be?

9. Learner: A wedding.
The lesson follows a typical T-P-T pattern where the teacher elicits 'What is writing?', which, when learners do not provide a response, relegates it into a starter. Interestingly, this starter uses both isiZulu and English in line C3:1, 'Konje iyini writing' to elicit the meaning of writing. The teacher then provides the expected response and proceeds to provide the focus of the lesson. She further code-switches (C3:3) 'Uma sibhala sibeka imicabango yethu, angithi?' to explain what writing is. In this extract, learners do not bid for nomination but the teacher simply nominates each learner. The next section of the lesson:

10. Teacher: Yes, RSVP. What does RSVP stand for? If we write RSVP in an invitation what do we want? To send you your reply usho ukuthi uyeza emcimbini angithi? [saying that you are coming to the function, isn't it?] Yes. So you reply very soon usho [saying] you will be coming and you phone the person whose number is given on the card. Why must you phone usho uyeza [saying you are coming] X [name of the learner]?

In this extract the teacher elicits the meaning of RSVP. When learners do not provide a response, the teacher goes ahead and provides the expected answer. Interestingly, the teacher's answer is a mixture of isiZulu and English. The switch between isiZulu and English is not necessarily triggered by the complexity of the answer - half of the answer is in isiZulu and another half in English (To send you your reply usho ukuthi uyeza emcimbini angithi? [saying that you are coming to the function, isn't it?]). In other words, the teacher indicates that RSVP is a reply and the content of the reply is given in isiZulu. After providing the answer, the teacher proceeds eliciting the reason for RSVP. Unlike the first elicitation, which was open to all learners, the second one is directed to one learner who is nominated to provide the answer. The teacher's nomination could be triggered by the first awkward silence which forced the teacher to provide the answer. However, providing the answer that learners are supposed to know might indicate that the teacher had not taught them effectively. Nominating one learner, therefore, serves to rescue the teacher from the perceptions of not having taught the learners successfully.

\section{Lesson 4, School D}

Duration of the lesson: $55 \mathrm{~min}$

1. Teacher: Today we are going to revise writing a narrative essay. But first, how do we define a narrative essay? How does it differ from other types of essays? A narrative essay, how do we write it?

2. LEARNER: It is a short story that talks about what happened.

3. Learner: A life story.

4. Learner: The writer is the narrator of the story.

5. Teacher: Good. So we say it's a short story [writing on the board]. We also say a writer could be sharing life experiences; and thirdly, the writer is also the narrator of the story. That is, it is written in the first person narration. Right? 
6. Learners: Yes, sir.

7. Teacher: What else?

8. Learner: You write the story in the past tense.

9. Teacher: Good. Those are just the basics. There is more to writing a narrative essay. You must think about what you tell in your story in an interesting way. Ukubhala ngendlela ehehayo [To write in an interesting way]. There are steps that we follow when we write a narrative essay, right?

10. Learners: Yes, sir.

The teacher elicited the meaning of a narrative. The teacher nominated learners to speak. The first learner provided a response. This is followed by another learner's response before the teacher's feedback. This shows that the learners' speaking turns are not controlled by the teacher in the classroom as we have seen in other lessons in this study. The teacher used code-switching to reiterate how learners should write their narratives 'Ukubhala ngendlela ehehayo' (to write in an interesting way).

\section{Lesson 5, School E}

Duration of the lesson: $55 \mathrm{~min}$

1. Teacher: What is the first step of writing an essay? Anyone who knows? Yes, over there?

2. Learner: We brainstorm the topic.

3. Teacher: No, I said the first step. You were not listening. Anyone?

4. Learner: We first choose a topic.

5. Teacher: Yes, we choose a topic for writing. What else?

6. Learner: We brainstorm the topic.

In this extract the teacher elicits the first step of writing an essay. The learner who is nominated provides an answer that is rejected by the teacher. The learner's answer irritates the teacher who went on to reprimand the learner for not having paid attention when the teacher taught the steps. Another learner is nominated who provides an answer that satisfies the teacher. The teacher then elicits the next step when another learner provides the same answer that the teacher had initially rejected. This indicates that the teacher regards writing as a rigid process that must follow specific steps without changing the order. However, this is not what normally happens in the writing class. The writing topic is usually provided by the teacher, which makes brainstorming the first step. Nevertheless, the teacher seems to be promoting the process approach to writing (Badger \& White 2000):

7. Teacher: Now I want you to choose a topic from a list of topics in your notes. Choose the topic and create a spider diagram and start to think about what information you need for your topic. Write as much information as you can. I give you $20 \mathrm{~min}$ to do that. You can use the back of your exercise books for this activity. Write the topic clearly so that I can check if your ideas are in line with your topic. Alright?

This extract confirms that the topics for writing are normally provided by the teacher. From the above extract the teacher provided learners with the time to implement the spider diagram technique to brainstorm ideas for their writing. The teacher also explained that he will check their ideas to provide feedback on whether the ideas are in line with the topics chosen by the learners. This classroom discourse further confirms the implementation of the process approach in the writing classroom. By providing feedback on the learners' ideas, it could be said that the teacher understands writing as a social practice. That is, the teacher understands his role of providing guidance and support as the knowledgeable adult in the classroom context.

\section{Discussion}

Classroom observation and analysis of the five writing lessons show classroom discourse that suggests different approaches to writing being implemented across the five schools. Extract A1:1-14 from School A shows the teacher eliciting the stages of the writing process from the learners. Different learners provide responses and they all give different stages of the writing process. These classroom interactions suggest that the teacher uses the process approach to teach writing. It also suggests that the teacher promotes classroom interactions and participation through an elicitation-response technique.

In the extract of a narrative lesson from School B, the teacher explains to learners how they should approach their own writing by brainstorming their topics to generate the ideas for their writing. The teacher emphasises the use of a mind map or a flow diagram for the planning stage of writing. They also stress that the planning will help learners to produce coherent ideas in a coherent manner. This extract suggests that the teacher used the process approach to teach the writing of a narrative in her classroom. Traces of a genrebased approach to writing were also noticed in this lesson when the teacher encouraged learners to also consider the tone and the mood, as well as feelings when crafting their texts (B2:17-52).

Classroom discourse from School C shows how the teacher elicited information that should appear on the invitation card. By drawing the card on the board, the teacher is providing learners with a model of an invitation card for the development of their own invitation cards. The modelling approach is most prominent in the genre-based approach to writing where the teachers bring a model text to be learned for learners to practise and master. The teacher did not actually bring the invitation card into the classroom; however, by drawing it on the board the learners got to see both the structure and the content of the invitation card. Through the question and answer method the teacher also engaged the learners in the brainstorming about the content for the invitation card. It can, therefore, be said that the lesson followed both the process and the genre approach to writing.

Extracts from School D show that the teacher is putting more emphasis on the structure of the text, the paragraphs, as well as the number of words that learners must produce. These 
elements are most prevalent in the product approach to writing where the focus is mostly on the final product instead of on the processes of writing. It could be speculated that the focus of the lesson was on the structure of the text, which is the revising stage of the process, and not necessarily the planning or the drafting stage, as the curriculum suggests that teachers may not necessarily teach all the stages of the writing process in one lesson but they may select the stage they want to emphasise. Nevertheless, based on the classroom observation, the focus on the structure implied a product approach. This suggests that teachers also use the product approach to teach writing.

A narrative lesson from School E followed the process approach. The teacher first elicited the elements of a narrative (E5:1) and then through question and answer engaged learners in the brainstorming of the topic (E5:6). The teacher then instructed learners to choose a topic and directed them to use the spider diagram technique he had taught them to generate ideas for their topics (E5:7). Learners were provided with time to practice the stages of writing in the classroom. In the later stages of Lesson 5, the teacher also provided time for the learners to write their introductions so that he/she could provide feedback. This indicates the social role of the teacher as the knowledgeable adult in the writing classroom, that is, the role of providing support and guidance through feedback. The following section summarises the findings of the study.

\section{Writing approaches employed by teachers}

Findings from the analyses of writing lessons indicate that the teachers in the five schools used three approaches to writing. Most prevalent in the writing classroom was the process approach, which views writing as a process that consists of different stages such a planning/pre-writing (selecting a topic and planning what to say); drafting/writing (putting a draft version on paper); revising (making changes to improve writing); editing/proofreading (evaluation of written work for refinement and improvement); and publishing (presenting the work for the reader) (Flower \& Hayes 1981). Over and above the process approach this study found that the product approach was used by some teachers to supplement the process approach. In such cases the study showed that the teachers used the product approach to emphasise the structure, organisation and conventions of the different genres they were teaching. This supports second language development and helps learners to become efficient writers. Data from lesson observations and analyses of writing lessons also reveal the use of the genre approach by the teachers to highlight the schematic structures of genres such as the friendly letter, narrative, speech writing and the invitation card (Mpiti 2016).

\section{Teaching strategies used by teachers}

Findings from the analyses of the writing lessons indicate that the teachers mostly used a question and answer method to teach writing in the five schools. This method entails that the teachers control the interactions in the classrooms through a nomination-response cycle. Without teacher nomination, the learners remain passive. On the flip side, the study observed that the teachers used this method to invite participation from different learners in the classroom. However, the study found that the types of questions that the teachers asked solicited one-word response or short responses. This meant that learners' second language production remained limited. The study also found limited interaction among learners in the writing classrooms. Even though the learners were seated in pairs, the classroom pedagogy did not promote learner-learner interaction, which is mostly favoured for the second language writing classrooms as it provides learners with an opportunity to learn together and to help each other. Vygotsky's (1978) socio-cultural learning theory connects learning and social interaction. Limited peer learning in the writing classroom could mean that the teachers are not aware of the sociocultural learning theory and the learning benefits of peer learning for the development of writing skills.

\section{Code-switching as a pedagogical tool}

The findings from the analyses of lessons suggest that teachers creatively employed code-switching for pedagogical purposes. Code-switching is defined differently by different scholars. Maluleke (2019) defines code-switching as an alternative use of two or more languages in a sentence or speech. In South Africa code-switching is a frequent and accepted mode of communication among bilingual or multilingual speakers. Songxaba, Coetzee and Molepo (2017) observe that codeswitching has become a natural aspect of bilingual or multilingual classrooms in South Africa. In situations where switching to isiZulu explained concepts better, the study found code-switching to enhance learners' understanding and thus fulfil an academic purpose. The notions of using learners' home languages to enhance cognition and development is iterated by Vygotsky (1978). Informed by these findings, the study suggests that code-switching is a useful learning resource in multilingual contexts where English is an obstacle to effective teaching and learning.

\section{Conclusion}

The success or limitations of teaching writing depends on a number of factors. Firstly, it depends on the teachers' knowledge and understanding of writing and approaches to writing. In this study the teachers seemed to understand the process approach they are expected to implement in their classrooms. Secondly, successful teaching of writing depends on the instruction methods. The teacher-centred pedagogy that was used in the selected schools undermined learner-learner interaction and peer learning, which are central to the sociocultural theory that underpinned this study. The types of questions asked by the teachers only necessitated that learners provide one-word answers or short responses. This again provided limited second language output in the writing classrooms. The traditional classroom also promoted individual thinking and learning. In the absence of collaborative writing 
tasks and peer support, weak learners remained weak (Badger \& White 2000). Collaborative activities allow learners to exchange ideas, write together, share feedback, support each other's language development and develop social skills and confidence in their writing (Badger \& White 2000). In this aspect the study, therefore, suggests that teachers need to be trained on interactive classroom pedagogy so that they are able to transform their writing classroom into social and supportive writing spaces for learners. Lastly, the study found codeswitching to be inevitable in second language writing classrooms where the teachers and learners are competent in more than one language. The study, therefore, concludes that code-switching, where it affords teachers and learners an opportunity to enhance teaching and learning of writing, should be used (Chikiwa \& Schafer 2016). It is suggested that future studies extend the findings to perceptions of teachers on the writing strategies they use in their writing classrooms.

\section{Acknowledgements Competing interests}

The authors have declared that no competing interest exists.

\section{Authors' contributions}

All authors contributed equally to this work.

\section{Ethical consideration}

University of Zululand approved the ethical clearance: UZREC 171110-030 PGM 2017/423.

\section{Funding information}

The research received no specific grant from any funding agency in the public, commercial or non-profit sectors.

\section{Data availability statement}

Data sharing is not applicable to this article as no new data were created or analysed in this study.

\section{Disclaimer}

The views and opinions expressed in this article are those of the authors and do not necessarily reflect the official policy or position of any affiliated agency of the authors.

\section{References}

Akinyenye, C. \& Pluddemann, C., 2016, 'The story of a narrative: Teaching and assessing English writing in a township school', Journal of the Reading Association of South Africa 7(1), 1-8. https://doi.org/10.4102/rw.v7i1.88
Akinyenye, C.M., 2012, 'Investigating approaches to the teaching of writing in English as a second language in senior phase classrooms in the Western Cape', Master's thesis, Faculty of Education, University of the Western Cape.

Badger, R. \& White, G., 2000, 'A process genre approach to teaching writing', English Language Teaching Journal 54(2), 153-160. https://doi.org/10.1093/elt/54.2.153

Blease, B. \& Condy, J., 2015, 'Teaching of writing in two rural multigrade classes in the Western Cape', Reading \& Writing 6(1), 1-9. https://doi.org/10.4102/rw.v6i1.58

Chikiwa, C. \& Schafer, M., 2016, 'Teacher code-switching consistency and precision in a multilingual mathematics classroom', African Journal of Research in Mathematics, Science and Technology Education 20(3), 244-255. https://doi.org/ 10.1080/18117295.2016.1228823

Creswell, J.W., 2009, Research design: Qualitative, quantitative, and mixed methods approaches, Sage, Los Angeles, CA.

DeLange, M., Dippenaar, H. \& Anker, J., 2018, 'Shared writing as first phase in writing instruction of intermediate phase Afrikaans Home Language Learners', A Journal for Language Learning 34(1), 33-46. https://doi.org/10.5785/34-1-704

Department of Basic Education, 2012, Curriculum Assessment Policy Statements (CAPS) Grade 10-12 English First Additional Language, Department of Basic Education, Pretoria.

Dornbrack, J. \& Atwood, M., 2019, Teaching writing in the FET phase, Literacy Association of South Africa, viewed 21 November 2019, from https://litasa.org.za/ assets/Download/Dornbrack.pdf.

Dornbrack, J. \& Dixon, K., 2014, 'Towards a more explicit writing pedagogy: The complexity of teaching argumentative writing', Reading \& Writing 5(1), 1-8. https://doi.org/10.4102/rw.v5i1.40

Escholz, P.A., 1980, 'The prose models approach: Using products in the process' in R.D. Timothy \& W.M. Ben (eds.), Eight approaches to teaching composition, National Council of Teachers of English, Urbana, IL.

Flower, L.S. \& Hayes, J.R., 1981, 'A cognitive process theory of writing', College Composition and Communication 32(4), 365-387. https://doi.org/10.2307/356600

Isleem, H.A.H., 2012, 'A suggested program based on individualized activities for developing Palestinian sixth graders' writing skills', Unpublished Master thesis, The Islamic University of Gaza, Palestine.

Julius, L.H., 2013, 'Teaching writing to Grade 5 English language learners in two Grahamstown East Schools, South Africa: A case study', Master's dissertation, Rhodes University.

Leach, J. \& Moon, B., 2008, The power of pedagogy, Sage, London.

Lee, I., 2008, 'Understanding teachers' written feedback practices in Hong Kong secondary classrooms', Journal of Second Language Writing 17, 69-85. https:// doi.org/10.1016/j.jslw.2007.10.001

Maluleke, M.J., 2019, 'Using code-switching as an empowerment strategy in teaching mathematics to learners with limited proficiency in English in South African schools', South African Journal of Education 39(3), 1-9. https://doi.org/10.15700/ saje.v39n3a1528

Mohile, M., 2014, 'An investigation into the English language writing strategies used by Polish EFL Secondary School Learners', Masters dissertation, Metropolitan University, London.

Mpiti, T., 2016, 'Teacher's and learners' experiences of learners' writing in English First Additional Language: A Case of IsiXhosa and Afrikaans Learners', PhD thesis, Faculty of Education, University of Fort Hare.

Ngubane, N., 2018, 'The nature and pedagogical implications of English first additional language writing among FET phase learners in the Pinetown district', PhD thesis, Faculty of Education, University of Zululand.

Nunan, D., 1999, Second language teaching \& learning, Heinle \& Heinle Publishers, New York, NY.

Pineteh, A., 2014, 'The academic writing challenges of undergraduate students: A South African case study', International Journal of Higher Education 3(1), 12-22. https://doi.org/10.5430/ijhe.v3n1p12

Raimes, A., 1991, 'Out of the woods: Emerging traditions in the teaching of writing', Teaching English to Speakers of Other Languages Quarterly 25(3), 407-430 https://doi.org/10.2307/3586978

Sinclair, J.M. \& Coulthard, R.M., 1975, Towards an analysis of discourse: The English used by teachers and pupils, Oxford University Press, London.

Songxaba, S.L., Coetzer, A. \& Malepo, J.M., 2017, 'Perceptions of teachers on writing space for code switching as a teaching strategy in the Eastern Cape province, South Africa', Reading \& Writing 8(1), 1-7. https://doi.org/10.4102/rw.v8i1.141

Tribble, C., 1996, Writing, Oxford University Press, Oxford.

Vygotsky, L.S., 1978, Mind in society: The development of higher psychological processes, Cambridge, Harvard University Press, MA. 